\title{
Differences in tail feather growth rate in storm-petrels breeding on the Northern and Southern hemisphere: a ptilochronological approach
}

\author{
Anne N.M.A. Ausems ${ }^{\text {Corresp., } 1}$, Katarzyna Wojczulanis-Jakubas ${ }^{1}$, Dariusz Jakubas \\ 1 Department of Vertebrate Ecology and Zoology, Faculty of Biology, University of Gdańsk, Gdańsk, Poland \\ Corresponding Author: Anne N.M.A. Ausems \\ Email address: anne.ausems@gmail.com
}

Moulting and breeding are costly stages of the avian annual cycle and may impose tradeoffs in energy allocation between them or in the timing of both stages. Here, we compared feather growth rates (FGR) of rectrices in adults between two pairs of small pelagic Procellariiformes species differing in moult-breeding strategies: the European storm-petrel Hydrobates pelagicus and Leach's storm-petrel Oceanodroma leucorhoa breeding in the Northern Hemisphere (Faroe Islands), showing moult-breeding overlap in tail feathers; and the Wilson's storm-petrel Oceanites oceanicus and black-bellied storm-petrel Fregetta tropica, breeding in the Southern Hemisphere (South Shetlands), temporally separating moult and breeding. We used ptilochronology (i.e. feather growth bar width) to reconstruct FGR reflecting relative energy availability during moult. Based on previous research, we expected positive correlations between feather length (FL) and FGR. Additionally, we expected to find differences in FGR relative to FL between the moult-breeding strategies, where a relatively higher FGR to FL indicates a higher energy availability for moult. To investigate if energy availability during moult in the studied species is similar to species from other avian orders, we used FGR and FL found in literature $(n=164)$ and this study. We fitted a phylogenetic generalized least squares (PGLS) model to FGR with FL, group (i.e. Procellariiformes vs non-Procellariiformes) and the interaction $\mathrm{FL} *$ group as predictors. As it has been suggested that Procellariiformes may form two growth bars per $24 \mathrm{~h}$, we fitted the same model but with doubled FGR for Procellariiformes (PGLSadj). The group term was significant in the PGLS model, but was not in the PGLSadj model, confirming this suggestion. Individually predicted FGR by the PGLSadj model based on FL, showed that the Southern species have a significantly higher FGR relative to FL compared to the Northern species. Additionally, we found no correlation between FL and FGR in the Northern species, and a positive correlation between FL and FGR in the Southern species, suggesting differences in the trade-off between feather growth and size between species from both hemispheres. The observed differences between the Northern and Southern Peer] reviewing PDF |'(2019:04:36621:3:0:CHECK 28 Aug 2019) 
species may be caused by different moult-breeding strategies. The Southern species may have had more energy available for moult as they are free from breeding duties during moult, while the Northern species may have had less free energy due to a trade-off in energy allocation between breeding and moulting. Our study shows how different moultbreeding strategies may affect relative nutritional condition or energy allocation during moult of migratory pelagic seabirds. 


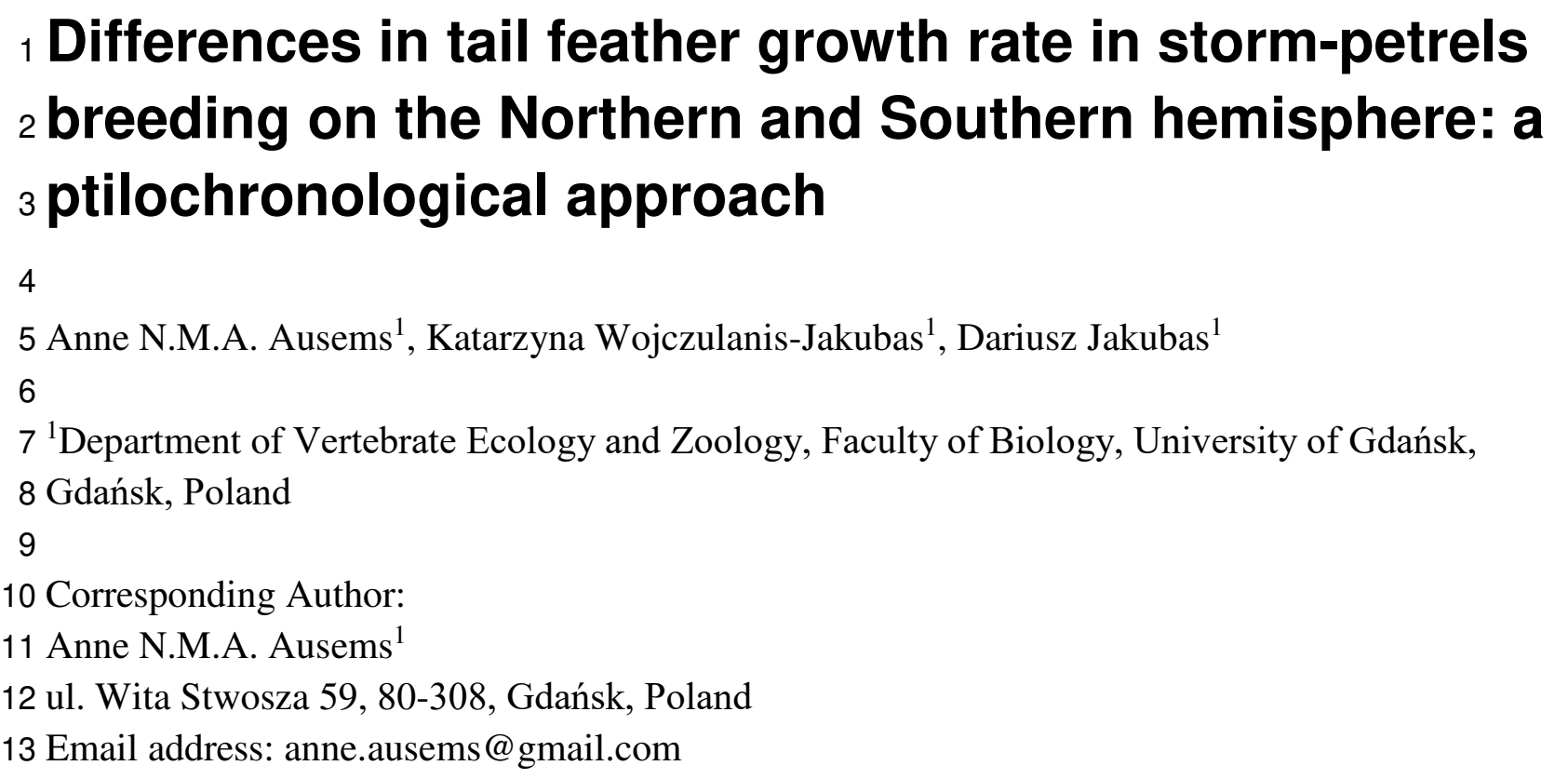




\section{Abstract}

15 Moulting and breeding are costly stages of the avian annual cycle and may impose trade16 offs in energy allocation between them or in the timing of both stages. Here, we compared 17 feather growth rates (FGR) of rectrices in adults between two pairs of small pelagic 18 Procellariiformes species differing in moult-breeding strategies: the European storm-petrel 19 Hydrobates pelagicus and Leach's storm-petrel Oceanodroma leucorhoa breeding in the 20 Northern Hemisphere (Faroe Islands), showing moult-breeding overlap in tail feathers; and the 21 Wilson's storm-petrel Oceanites oceanicus and black-bellied storm-petrel Fregetta tropica, 22 breeding in the Southern Hemisphere (South Shetlands), temporally separating moult and 23 breeding. We used ptilochronology (i.e. feather growth bar width) to reconstruct FGR reflecting 24 relative energy availability during moult. Based on previous research, we expected positive 25 correlations between feather length (FL) and FGR. Additionally, we expected to find differences 26 in FGR relative to FL between the moult-breeding strategies, where a relatively higher FGR to $27 \mathrm{FL}$ indicates a higher energy availability for moult. To investigate if energy availability during 28 moult in the studied species is similar to species from other avian orders, we used FGR and FL 29 found in literature $(n=164)$ and this study. We fitted a phylogenetic generalized least squares 30 (PGLS) model to FGR with FL, group (i.e. Procellariiformes vs non-Procellariiformes) and the 31 interaction $\mathrm{FL} *$ group as predictors. As it has been suggested that Procellariiformes may form 32 two growth bars per $24 \mathrm{~h}$, we fitted the same model but with doubled FGR for Procellariiformes 33 (PGLSadj). The group term was significant in the PGLS model, but was not in the PGLSadj 34 model, confirming this suggestion. Individually predicted FGR by the PGLSadj model based on 35 FL, showed that the Southern species have a significantly higher FGR relative to FL compared to 36 the Northern species. Additionally, we found no correlation between FL and FGR in the 37 Northern species, and a positive correlation between FL and FGR in the Southern species, 38 suggesting differences in the trade-off between feather growth and size between species from 39 both hemispheres. The observed differences between the Northern and Southern species may be 40 caused by different moult-breeding strategies. The Southern species may have had more energy 41 available for moult as they are free from breeding duties during moult, while the Northern 42 species may have had less free energy due to a trade-off in energy allocation between breeding 43 and moulting. Our study shows how different moult-breeding strategies may affect relative 44 nutritional condition or energy allocation during moult of migratory pelagic seabirds.

45

\section{Introduction}

$47 \quad$ Moulting and breeding are energetically costly stages of the annual cycle of birds. The 48 costs of feather synthesis can be illustrated by the fact that metabolic rate during moult increases 49 by more than $100 \%$ compared to pre-moulting (Lindström, Visser \& Daan, 1993). Feather 50 production costs are linked with body mass in a way that moult is relatively more demanding for 51 smaller birds (Lindström et al., 1993). Additionally, moult gaps in the remiges and/or rectrices 52 formed after losing old feathers reduce aerodynamic performance, mostly through affecting 
53 manoeuvrability (Hedenström \& Sunada, 1999; Slagsvold \& Dale, 1996) and less so through 54 increased flight costs (Hedenström \& Sunada, 1999).

55 The costs of breeding (e.g. incubation and chick provisioning) are apparent in the 56 increased field metabolic rates (e.g. 11\% from incubation to chick rearing in Australasian 57 gannets, Morus serrator) (Green et al., 2013) and increased stress levels (e.g. higher feather 58 corticosterone concentrations in giant petrels, Macronectes spp.) in successful compared to failed 59 breeders (Crossin, Phillips, Lattin, Romero \& Williams, 2013). Increased reproductive costs 60 negatively affected the breeding success in the following year, and birds may even forego 61 breeding if the costs are too high (Crossin et al., 2013; Minguez, 1998; Pratte, Boadway, 62 Diamond, \& Mallory, 2018).

63 Due to the high energetic costs of moulting and breeding, trade-offs may emerge 64 regarding energy allocation between them. Indeed, in many avian species these two life-stages 65 are temporally separated, with complete moult following the breeding period. Failed breeders 66 and non-breeders often take advantage of the absence of breeding duties by advancing moult 67 (Alonso, Matias, Granadeiro \& Catry, 2009; Barbraud \& Chastel, 1998; Crossin et al., 2013; 68 Hemborg, Sanz \& Lundberg, 2001; Mumme, 2018; Ramos, Llabrés, Monclús, López-Béjar \& 69 González-Solís, 2018). In contrast, individuals that breed relatively late in the season (Stutchbury 70 et al., 2011), or that have higher foraging costs during the breeding period (Alonso et al., 2009), 71 moult later in the season. Moreover, individuals of some species may suspend moult until they 72 arrive at the wintering areas (Catry et al., 2013; Ramos, Militão, González-Solís, \& Ruiz, 2009), 73 providing some flexibility in allocation of energy between moulting, breeding and migration. 74 The extent of this flexibility partially depends on environmental circumstances (e.g. day-length 75 linked to latitude or food availability) (Hemborg et al., 2001), and the trade-off between 76 moulting and breeding may even differ strongly between closely related species (e.g. in 77 Northern, Fulmarus glacialis, and Southern, F. glacialoides, fulmars; Barbraud \& Chastel, 78 1998). For instance, some seabird species overlap breeding and moulting, although populations 79 with higher foraging costs show less overlap than populations with lower costs (e.g. in Cory's 80 shearwaters, Calonectris diomedea borealis; Alonso et al., 2009). Moult-breeding overlap may 81 therefore only be possible when energetic demands can be met, e.g. when food availability is 82 high (Alonso et al., 2009; Barbraud \& Chastel, 1998). Likewise, moult-breeding overlap seems 83 more prevalent in sedentary than migratory species (Bridge, 2006), though several migratory 84 species adopt this strategy as well (Alonso et al., 2009; Barbraud \& Chastel, 1998; Ramos et al., 85 2009).

86 Investigating the trade-off in energy allocation between moulting and breeding may be 87 challenging in pelagic seabirds as they are only available for researchers when they come to land 88 for breeding. As at least part of the moulting period is often completed away from the breeding 89 colony, studying their energy management during feather growth may prove difficult. 90 Ptilochronology may offer a way to retrospectively determine the relative amount of energy 91 availability during moulting in seabirds, and so evaluate their energy allocation towards feather 92 production. The method is based on feather growth rate, which is determined by the mean feather 
93 growth bar width (Grubb, 1989, 2006). Growth bars are alternating light and dark bands formed 94 during feather growth. It is generally assumed that one growth bar is formed over a period of 24 95 h (Grubb, 2006; Jovani, Blas, Navarro \& Mougeot, 2011; White \& Kennedy, 1992), making it a 96 convenient measure for feather growth rate.

97 Mean growth bar width is linked with nutritional status, with birds foraging in areas with 98 higher food availability having relatively larger growth bars (Grubb, 1989; Hill \& Montgomerie, 99 1994). However, within species, growth bar width has also been related to other feather traits 100 [i.e. positively to feather size (de la Hera, Pérez-Tris \& Tellería, 2009; le Tortorec et al., 2012; 101 Pérez-Tris, Carbonell \& Tellería, 2002), though not in all species (de la Hera, Pérez-Tris \& 102 Tellería, 2009; Pérez-Tris et al., 2002), and negatively to feather quality (Marzal et al., 2013)]. 103 Inter-species comparisons have shown that growth bar width is positively correlated with feather 104 length and mass. This correlation is negatively allometric, such that species with larger feathers 105 have relatively lower growth rates per unit of feather length (de la Hera, DeSante \& Milá, 2012). 106 A similar correlation has been found between feather growth rate and body size, with larger 107 species having higher absolute feather growth rates, but lower relative growth rates per unit of 108 body size (Rohwer, Ricklefs, Rohwer \& Copple, 2009).

109 The aim of our study was to compare relative energy availability during moult between 110 pelagic storm-petrel species with contrasting moult-breeding strategies, i.e. moult-breeding 111 overlap or non-breeding moult. In order to understand the inter- and intra-specific differences in 112 energy availability during moult we compared feather growth rates with feather length. 113 Additionally, to infer the relative energy allocation for each of the species towards moulting, we 114 compared their observed feather growth rate with feather growth rate data for other species found 115 in literature. This study is the first to compare differences in expected feather growth rates 116 between similar species breeding in both hemispheres. Due to their small size and pelagic life117 style the non-breeding period of storm-petrels can be hard to study but thanks to recent 118 developments in technology specific migration routes of some species are being discovered 119 (Pollet et al, 2014; Halpin et al., 2018; Martinez et al, 2019, Lago, Austad \& Metzger, 2019). 120 Our study adds to the understanding of storm-petrel migratory, moulting and breeding strategies 121 by giving some, admittedly indirect, insights into their energy management.

122 Since larger feathers have been linked to a higher growth rate both within (de la Hera, 123 Pérez-Tris \& Tellería, 2009; le Tortorec et al., 2012; Pérez-Tris et al., 2002) and between species 124 (de la Hera et al., 2012), we expected to find positive correlations between feather length and 125 growth bar width both within and between the four storm-petrel species. Since the studied 126 species adopt contrasting moult-breeding strategies, we expected to find differences in feather 127 growth rate relative to feather length between the two strategies, indicating differences in relative 128 energy allocation towards moult.

129

\section{Materials and Methods}


132 We studied European storm-petrels, Hydrobates pelagicus (hereafter also ESP), and 133 Leach's storm-petrels, Oceanodroma leucorhoa (hereafter also LSP), breeding sympatrically in 134 the Northern Atlantic, and Wilson's storm-petrels, Oceanites oceanicus (hereafter also WSP), 135 and black-bellied storm-petrels, Fregetta tropica (hereafter also BBSP), breeding sympatrically 136 in the Maritime Antarctic. The European storm-petrel is the world's smallest pelagic seabird, 137 while the Wilson's storm-petrel is the smallest endotherm breeding in the Antarctic. Black138 bellied and Leach's storm-petrels are similar in body morphology, apart from tarsus length, and 139 both are significantly larger than the European and Wilson's storm-petrels (Carboneras et al., 140 2017). All four species are migratory, and move towards and sometimes beyond the equator, 141 during the non-breeding season. Though morphologically similar (Flood \& Thomas, 2007), 142 storm-petrels are divided into two families: the Northern Hydrobatidae and the Southern 143 Oceanitidae (Penhallurick \& Wink, 2004; Rheindt \& Austin, 2005; Robertson et al., 2016). 144 The breeding season for all species takes several months from first arrival at the colony to 145 fledging and takes place during summer (boreal and austral in Northern and Southern 146 hemispheres respectively), with chicks fledging in late summer (egg laying until fledging takes 147 on average 3,5 months for all species) (Carboneras et al., 2017; Cramp et al., 1977; Wasilewski, 148 1986). The diets of the studied storm-petrel species consist mostly of crustaceans and myctophid 149 fish, though the Northern species eat relatively more fish than crustaceans compared to the 150 Southern species (Ainley, O’Connor, \& Boekelheide, 1984; Ainslie \& Atkinson, 1936; Büßer, 151 Kahles, \& Quillfeldt, 2004; Croxall \& North, 1988; Croxall \& Prince, 1980; D’Elbée \& Hémery, 152 1998; Hahn, Quillfeldt, \& Reinhardt, 1998; Hedd \& Montevecchi, 2006; Quillfeldt, 2002; 153 Ridoux, 1994; Wasilewski, 1986). Wilson's and black-bellied storm-petrels start moulting after 154 the breeding period (Beck \& Brown, 1972) while European and Leach's storm-petrels start 155 moulting during the breeding period, exhibiting moult-breeding overlap (Ainley, Lewis \& 156 Morrell, 1976; Amengual et al., 1999; Arroyo, Mínguez, Palomares \& Pinilla, 2004; Bolton \& 157 Thomas, 2001).

\section{$158 \quad$ Sample collection}

159 We sampled European $(\mathrm{n}=52)$ and Leach's storm-petrels $(\mathrm{n}=55)$ in the Northern 160 Hemisphere (hereafter Northern species) on the island of Mykines, Faroe Islands $\left(62^{\circ} 05^{\prime} \mathrm{N}\right.$, $\left.16107^{\circ} 39^{\prime} \mathrm{W}\right)$. During the breeding period of 2018 we captured adults in mist nets at night, placed in 162 a mixed colony. We studied Wilson's $(n=228)$ and black-bellied storm-petrels $(n=32)$ in the 163 Southern Hemisphere (hereafter Southern species), on King George Island, South Shetland 164 Islands, Antarctica (62 $09^{\prime}$ S, 58 $\left.27^{\prime} \mathrm{W}\right)$. During the breeding periods of 2017 and 2018 we 165 captured adults in mist nets placed in the colonies and took parents from the nests.

166 We collected the right outermost rectrix from adults of the four species of storm-petrels. 167 In 201832 adults were recaptured that were previously caught in 2017, with fully formed 168 rectrices. Additionally, one Wilson's storm-petrel was recaptured within 2018 with a fully 169 regrown rectrix, though the regrown feather has not been used for the statistical analyses. We did 170 not notice anything untoward in their tail feathers, or during the analyses (e.g. obvious outliers), 
171 which leads us to assume that our plucking of the feathers did not cause long-term harm to the 172 birds. See below for pseudo-replication management.

173 All individuals of the Northern species and some individuals of the Southern species 174 were captured in mist-nets, which could lead to uncertainty in the breeding stage of the adults. 175 By capturing birds in a mist-net it becomes harder to determine the breeding status of the 176 sampled adults, as sub-adults may be caught while prospecting the colony (floaters)(Sanz177 Aguilar et al., 2010). Especially when using tape-lures, prospecting birds may be attracted to the 178 net (Furness \& Baillie, 1981; Amengual et al. 1999). However, breeding birds can be identified 179 by their readiness to regurgitate and the presence of a brood patch (Furness \& Baillie, 1981). We 180 did not use tape-lures for the European storm-petrels during capturing events, decreasing the 181 likelihood of catching floaters. We did use tape-lures for the Leach's storm-petrels, which could 182 have increased the chances of attracting floaters. However, almost all Leach's storm-petrels were 183 observed to readily regurgitate, and all had either fully bare brood patches, or brood patches with 184 only few feathers present. This leads us to assume that at least the vast majority of the sampled 185 birds were breeders.

186 Birds were handled under licence of the Statens Naturhistoriske Museum, Københavns 187 Universitet C 1012 and with permission of the Polish National SCAR, Institute of Biochemistry 188 and Biophysics (Permit for entering the Antarctic Specially Protected Area No. 3/2016 \& No. 189 08/2017, Permit for taking or harmful interference of Antarctic fauna and flora No. 6/2017 \& No. 190 7/2016). Permission to enter the study site on Mykines was sought through local land-owners.

$191 \quad$ Feather measurements

192 We measured feather length (FL) from the tip to the base of the calamus with calipers to 193 the nearest $0.1 \mathrm{~mm}$. We measured growth bar width by placing the feather on a white paper 194 background and marking the tip and the base of the calamus, and each visible growth bar in the 195 vane area of the feather before rounding of the tip and above the white area, with a pinprick. We 196 then used calipers to measure the distances between each pinprick on the background to the 197 nearest $0.1 \mathrm{~mm}$, following Grubb (1989). A new piece of paper was used for each feather. We 198 used mean growth bar width per feather as a proxy for feather growth rate (FGR).

$199 \quad$ Statistical analyses

200 Since we sampled the Southern species during two field seasons, we investigated the 201 inter-annual differences in FGR and FL using a Welch t-test (t.test, package stats in R version 202 3.6.1 (R Core Team, 2019)). FGR was significantly higher in 2017 compared to 2018 for the 203 Wilson's but did not differ significantly for black-bellied storm-petrels (Welch t-test; WSP: $\mathrm{t}_{163.69}$ $204=3.192, p=0.002$; BBSP: $\left.t_{29.343}=-0.901, p=0.375\right)$. However, although significant for the 205 Wilson's storm-petrels, we deemed the absolute differences in FGR between the years small 206 enough (high overlap of the $95 \%$ confidence ellipses, Fig. S1) to justify pooling the data. FL did 207 not differ significantly between the years for either species (Welch t-test; WSP: $\mathrm{t}_{216.29}=-0.549, \mathrm{p}$ $208=0.584$; BBSP: $\left.t_{29.706}=-0.519, \mathrm{p}=0.608\right)$, and therefore we also pooled these data.

209 Since some individuals were caught in both years ( $\mathrm{n}=28$ for WSP, $\mathrm{n}=3$ for BBSP) we 210 assessed the effect of pseudo-replication by comparing the mean values of FL and FGR between 
211 the seasons of 2017 and 2018 for the Wilson's and black-bellied storm-petrels individuals 212 captured in both years. We found no significant differences between the means of both seasons 213 for either species (Paired t-test; FL: WSP: $\mathrm{t}_{27}=-0.993, \mathrm{p}=0.330$; BBSP: $\mathrm{t}_{2}=0.096, \mathrm{p}=0.932$; 214 FGR: WSP: $\mathrm{t}_{27}=1.469, \mathrm{p}=0.153$; BBSP: $\left.\mathrm{t}_{2}=-1.023, \mathrm{p}=0.414\right)$. Thus, in further analyses based 215 on individuals, to avoid pseudo-replication, we used the mean values per individual instead of 216 repeated measurements which reduced the sample size to $n=200$ unique individuals for the 217 Wilson's storm-petrels and to $n=29$ unique individuals for the black-bellied storm-petrels. 218 To compare FL and FGR among species we used univariate tests. Due to inequality of 219 variances (Fligner-Killeen test, fligner.test, package stats) of FL $\left(\chi^{2}=10.87, \mathrm{df}=3, \mathrm{p}=0.012\right.$ ) 220 we used non-parametric Kruskal-Wallis and post-hoc Dunn tests (dunn.test, package dunn.test) 221 for all inter-species comparisons. To examine the relationships between FL and FGR for each 222 species, we used Spearman's rho correlation (cor.test, package stats) because we did not 223 necessarily expect linear relationships after plotting FGR and FL data for multiple species found 224 in literature (Fig. S2). Additionally, we chose not to transform the data to make them linear as 225 the transformations needed differed between the species and would inhibit inter-specific 226 comparisons.

227 To investigate if the observed FGR of the studied species was higher or lower than 228 expected (i.e. what their energy availability was) we fitted a phylogenetic generalized least 229 square (PGLS) model ( $g l s$, package $n l m e$ ) with Pagel's $\lambda$ (corPagel, package ape) to multi230 species data. The full model contained FGR as response variable with FL, group [group 1: non231 Procellariiformes $(n=162)$; group 2: Procellariiformes $(n=6)]$ and the interaction FL * group as 232 predictor variables (PGLS model). We used $\triangle$ AIC to determine if the updated model had a better 233 fit, and dropped terms that did not improve the model.

234 For the PGLS model we used FGR and FL data found in literature ( $\mathrm{n}=164$ species, 194 235 observations) and from this study ( $n=4$ species)(Table S1). For species with multiple records of 236 FGR and FL, we averaged the values per species. We searched for suitable studies in the Web of 237 Science Database (https://www.webofknowledge.com; 05-11-2018) using ptilochronology, 238 growth bars and feather growth rate as keywords. We then only selected papers if they contained 239 FGR and FL measurements in SI units.

240 We reconstructed the phylogeny based on the most recent complete avian time-calibrated 241 phylogeny (Jetz et al 2012) with a backbone tree developed by Ericson et al. (2006). To account 242 for phylogenetic uncertainty we calculated the consensus tree, based on 100 alternative trees, 243 downloaded from the BirdTree database (http://www.birdtree.org; Jetz et al. 2012). We corrected 244 for FGR and FL left-skewed data by $\log 10$ transformation of the data.

245 The feather types (rectrix or primary) used to determine FGR differed between studies, 246 but FGR is highly correlated between both types (Saino et al. 2012). A comparison of correlation 247 coefficients for a PGLS model with only rectrices $(n=129)$ and a PGLS model with only 248 primaries $(\mathrm{n}=44)$, using Fisher's $\mathrm{Z}$ (cocor.indep.groups, package cocor) showed no significant 249 difference $(\mathrm{z}=1.91, \mathrm{p}=0.056)$ (Table S3). Feather type was thus not used as a predictor in the 250 PGLS models. 
251 Langston and Rohwer (1996) suggested that in the Procellariiformes the relationship 252 between FGR and FL may differ from that of other species, i.e. form two growth bars per $24 \mathrm{~h}$ 253 due to foraging on prey that show diel migration. To test this possibility we firstly ran the PGLS 254 model with raw data. Then, we fitted identical PGLS models (i.e. FGR FL, FGR FL + Group 255 and FGR FL * Group) but doubled the FGR values for the Procellariiformes (PGLSadj), and 256 again dropped terms that did not improve the model. We could not compare the models with the 257 raw and adjusted data directly with each other, as they have different data sets, but with this 258 approach we could show the effect of Group on the model fit for both data sets.

259 We predicted FGR based on individual FL inserted into the PGLSadj model, and then 260 calculated the residual difference with observed FGR doubled. As Fligner-Killeen tests showed 261 variance inequality in the residuals between the species $\left(\chi^{2}=24.339, \mathrm{df}=3, \mathrm{p}<0.001\right)$ and 262 hemispheres $\left(\chi^{2}=26.077, \mathrm{df}=3, \mathrm{p}<0.001\right)$ we used non-parametric Kruskal-Wallis and Dunn 263 post-hoc tests to compare the differences between the species. To compare the residuals between 264 the two hemispheres, and thus moult-breeding strategies, we used Welch two-sample t-tests as 265 they are robust for variance differences (t.test, package stats). To determine whether the residuals 266 where positively or negatively different from zero, and thus if energy availability was relatively 267 high or low, we used one-sample Student's t-tests for each species (t.test, package stats). 268

269

$270 \quad$ Feather characteristics

271 We found significant differences between the species in FGR and FL (Kruskal-Wallis 272 test, FGR: $\chi^{2}=214.35, \mathrm{p}<0.001$; FL: $\chi^{2}=248.35, \mathrm{p}<0.001$ ). Post-hoc tests (Dunn test, $\mathrm{p}<$ 2730.001 ) revealed that black-bellied storm-petrels had a higher FGR than Wilson's storm-petrels 274 and the Southern species had a higher FGR than the Northern species (Table 1). FL differed 275 significantly between all species pairs (Dunn-test, $\mathrm{p}<0.001$ ) except between black-bellied and 276 Leach's storm-petrels (Table 1). Only the Southern species showed a significant positive 277 correlation between FGR and FL, with Wilson's storm-petrels showing a weak positive 278 correlation (Spearman correlation, $\mathrm{r}_{\mathrm{s}}=0.215, \mathrm{p}=0.002$ ) and black-bellied storm-petrels a 279 moderately positive correlation $\left(\mathrm{r}_{\mathrm{s}}=0.513, \mathrm{p}=0.04\right)$ (Fig. 1, Table 2). For the Northern species 280 we found no correlation between FGR and FL ( $\mathrm{p}>0.05)$ (Table 2).

$281 \quad$ Relative energy availability

282 In the full PGLS model (AIC = -497.59), FL $(p<0.001)$ and group (i.e. Procellariiformes 283 vs non-Procellariiformes) had a significant effect $(\mathrm{p}<0.001)$ on FGR but the interaction FL * 284 group did not $(\mathrm{p}=0.729)$ (Fig. 2A, Table 3). The PGLS model with group as a predictor 285 (hereafter optimised PGLS model) was better $($ AIC = -499.47) than the PGLS model without 286 group $(\mathrm{AIC}=-484.99, \Delta \mathrm{AIC}=14.48)($ Table 4$)$. The model with group and interaction did not 287 differ from the model without the interaction $(\mathrm{AIC}=-497.59, \Delta \mathrm{AIC}=1.88)$. After multiplying 288 Procellariiformes' FGR by two (i.e. PGLSadj), FL still had a significant effect on FGR (p < $2890.001)$ (Fig. 2B, Table 3). Neither group $(\mathrm{p}=0.912)$ nor the interaction FL * group was 290 significant $(\mathrm{p}=0.729)($ Table 3$)$. The PGSLadj model without the group predictor (AIC = - 
291 501.46) was not different from the PGLSadj model including group (AIC $=-499.47, \Delta \mathrm{AIC}=$ 292 1.99) nor was the PGLSadj model including group different from the model including group and 293 interaction $(\mathrm{AIC}=497.59, \Delta \mathrm{AIC}=1.88)($ Fig. $2 \mathrm{~B}$, Table 4).

294 The individual residuals of predicted FGR based on the optimized PGLS model differed 295 significantly between the studied storm-petrel species (Kruskal-Wallis; $\chi^{2}=198.92, \mathrm{df}=3, \mathrm{p}<$ 296 0.001)(Table 5) and hemispheres (Welch t-test, p < 0.001)(Fig. 3). The residuals for the Southern 297 species were significantly higher than those of the Northern species (mean Southern $=0.126$, 298 mean Northern $=-0.091, \mathrm{t}_{158.56}=-21.371$ ). The residuals differed significantly from zero for all 299 four species. Both Northern species had negative residuals, while both Southern species had 300 positive residuals (Student's t-test, ESP: $\mathrm{t}_{51}=-5.847, \mathrm{p}<0.001 ; \mathrm{LSP}: \mathrm{t}_{54}=-8.367, \mathrm{p}<0.001$; 301 WSP: $\left.\mathrm{t}_{199}=25.310, \mathrm{p}<0.001 ; \mathrm{BBSP}_{28}=14.460, \mathrm{p}<0.001\right)($ Fig. 3, Table 6).

302

303

\section{Discussion}

304

The Spearman's rho correlations showed significant, positive relationships between mean 305 growth bar width and feather length for the Southern storm-petrel species, but not for the 306 Northern species. Additionally, using the PGLS model, we found that the Southern species had a 307 higher feather growth rate than predicted while the Northern species had a lower feather growth 308 rate than predicted.

309 The difference in residual length between the studied species, and between the 310 hemispheres may be associated with a difference in relative energy availability during moulting 311 between species of both hemispheres, possibly caused by their different moult-breeding strategy. 312 The Southern species, both moulting during the non-breeding period (Beck \& Brown, 1972), are 313 free from breeding duties during moult and may use all available energy for feather synthesis, 314 while the Northern species, showing moult-breeding overlap (Amengual et al., 1999; Arroyo et 315 al., 2004; Bolton \& Thomas, 2001), have to allocate that energy between moulting and breeding. 316 The differences between storm-petrels from both hemispheres in trade-offs in energy allocation 317 between moulting and breeding may affect the correlations between feather length and feather 318 growth rate, resulting in a lack of significant correlations between feather length and mean 319 growth bar width in the Northern species in contrast to significant relationships between feather 320 length and mean growth bar width in the Southern species.

$321 \quad$ Moult-breeding overlap in the Northern species has so far only been shown in the 322 Mediterranean subspecies of the European storm-petrel (Hydrobates pelagicus melitensis) 323 (Amengual et al., 1999; Arroyo et al., 2004), in a British population of European storm-petrels 324 (Scott 1970 in Cramp et al., 1977), in Canadian populations of the Leach's storm-petrel (Ainley 325 et al., 1976), but the overlap extend is not (yet) generally accepted in Northern populations. 326 However, preliminary stable-isotope analyses show that tail feather isotopes of the Northern 327 species are more closely matched with blood isotopes collected during the breeding season, than 328 those of the Southern species (Ausems et al, in prep.). This seems to indicate that both the 329 feathers and blood were synthesised under more similar foraging conditions and in similar 
330 foraging, strengthening our conviction that the Northern species at least partially overlap their 331 tail moult and breeding.

332 Austral summer is short and primary production is highest only in favourable conditions 333 (i.e. longer daylight hours and retreating sea ice) (Arrigo, van Dijken \& Bushinsky, 2008; 334 Murphy et al., 2016). The peak abundance of the main prey of the Southern storm-petrels, 335 Antarctic krill, Euphausia superba, usually lasts from December to February (FAO, 2019; Ross 336 \& Quetin, 2014). The relatively short period of high food abundance and possible competition 337 over it [e.g. from penguins, whales and krill fisheries (Barlow et al., 2002; Descamps et al., 338 2016; Ratcliffe et al., 2015)] could inhibit the Southern storm-petrels from overlapping moult 339 and breeding as there is no longer enough food available at the end of the breeding season. 340 Additionally, compared to the North Atlantic and Arctic ocean, the highly productive 341 oceanographic features in the Southern Ocean, such as ocean fronts and eddies, occur over larger 342 spatial scales and are usually farther away from the breeding colonies, forcing the birds to take 343 longer foraging trips (Bost et al., 2009). During the non-breeding period birds free from the 344 constraint of central-place foraging may exploit these highly productive areas freely, which may 345 explain the relatively higher than predicted daily feather growth rate of the Southern species. 346 In contrast, both Northern storm-petrels have been reported to show moult-breeding 347 overlap, including the moult of tail feathers (Ainley et al., 1976; Amengual et al., 1999; Arroyo 348 et al., 2004; Bolton \& Thomas, 2001), though Leach's storm-petrels seem to start moulting 349 relatively earlier in the breeding season than European storm-petrels. In the North Atlantic, 350 around the Faroe Islands, primary production peaks over a longer period (Eliasen, 2017) as it is 351 not linked to sea ice cover. Thus, food abundance might still be sufficient for moulting at the end 352 of the breeding season for the Northern species. However, primary production varies strongly 353 between years, which could lead to distinct inter-annual differences in food abundance for the 354 storm-petrels (Bonitz, Andersson, Trofimova \& Hátún, 2018; ICES, 2005, 2008). As food 355 availability may thus be unpredictable for the Northern species during breeding, individuals may 356 make different choices in prioritising either moult or reproduction, leading to obscured 357 relationships between mean growth bar width and feather length.

$358 \quad$ Langston and Rohwer (1996) suggested that Laysan albatrosses (Phoebastria 359 immutabilis) may form two growth bars per $24 \mathrm{~h}$ because their main prey (i.e. various squid 360 species) is active at night and the albatrosses forage for them at dawn and dusk. This would 361 result in two activity-rest cycles per $24 \mathrm{~h}$, which would explain the formation of two growth bars 362 daily as growth bar formation has been linked to sleep or rest rhythms (Jovani et al., 2011). 363 Indeed, after doubling the feather growth rate of the Procellariiformes, their correlation between 364 feather growth rate and feather length was very similar to that of the other orders (Fig. 2B), as 365 shown by the lack of a significant group effect in the PGLSadj model. This seems to confirm 366 Langston and Rohwer's (1996) suggestion that Procellariiformes form two growth bars per $24 \mathrm{~h}$. 367 The four studied storm-petrel species may also have two activity-rest cycles per $24 \mathrm{~h}$, which is 368 consistent with the main prey activity of the studied storm-petrels during the breeding season, 369 myctophid fish and krill. These prey species have a nocturnal activity similar to the prey of the 
370 albatrosses (Hedd \& Montevecchi, 2006; Siegel, 2012), and several seabirds, including storm371 petrels, forage in more oceanic habitats during the non-breeding period where they seem to 372 increase their intake of myctophid fish (Watanuki \& Thiebot, 2018).

373 We are aware of several possible limitations of the present study. Although growth bar 374 widths have originally been linked to relative nutritional condition (Grubb, 1989; Hill \& 375 Montgomerie, 1994), it is not a direct measurement of food availability and the results should be 376 interpreted with caution in that regard (Murphy and King, 1991). In this study we used feather 377 growth rate as a way to retrospectively infer energy availability during moulting, as direct 378 examinations of diet and food availability during moulting were impossible due to the pelagic 379 nature and small body size of our study species. In order to put the feather growth rates observed 380 in our study species into perspective, we compared their growth rates with data found in 381 literature. However, while the reported measuring methods where similar between the studies, 382 sampling techniques may have differed. In some studies samples were taken from museum 383 specimens (e.g. de la Hera, DeSante \& Milá, 2012; Rohwer et al., 2009) while others collected 384 samples from live birds (e.g. de la Hera et al., 2012). This could lead to a bias in the condition of 385 the birds sampled, as museum specimens may come from individuals in relatively poor health, or 386 from relatively young individuals. Sample sizes per species ranged between 1 and 54 (de la Hera 387 et al., 2012) and for some species multiple sources were found (e.g. Sitta carolinensis: de la 388 Hera, DeSante \& Milá, 2012; Dolby \& Grubb, 1998; Grubb \& Cimprich, 1990). Especially 389 Passeriformes where highly represented ( $\mathrm{n}=160$ observations) in the model, while orders with 390 larger species were under-represented. The model may therefore be less appropriate for larger 391 species, but since the four storm-petrel species studied fall in a highly represented body size 392 category in the model we feel it is appropriate to use here. Due to differences in the studied 393 species' availability, large differences in sample sizes in our research occurred: the Northern 394 species were comparatively abundant during mist-netting sessions, while the Southern species 395 were not. Additionally, nests of Wilson's storm-petrels were more accessible and concentrated 396 than black-bellied storm-petrel nests, which were spread out over larger areas and more often 397 located on inaccessible cliffs and ledges. Nevertheless, our study provides the first comparison of 398 relative energy availability during tail-feather moult of storm-petrels differing in moult-breeding 399 strategies and breeding in different hemispheres.

400 Our results suggest that for many pelagic seabirds ptilochronology may be a useful, non401 invasive, and often only feasible, tool to study their relative energy allocation to feather growth 402 during the non-breeding period when they are hardly accessible to researchers. Due to their 403 specific life-history traits, pelagic seabirds may be especially interesting for ptilochronology 404 studies as one may expect different patterns of feather growth compared to other species. 405

406

407 We expected to find positive correlations between feather length and feather growth rate 408 both within and between species and to find differences in relative energy availability during 409 moulting between species with differing moult-breeding strategies. The results of our analyses 
410 showed distinct differences in relative energy availability between four species of storm-petrels. 411 The Southern species had a higher feather growth rate than predicted by a model based on data 412 from multiple species and orders, while the Northern species had a lower feather growth rate 413 than predicted. We suggest that all these differences can be attributed to the different moult414 breeding strategies the species adopt, as the Southern storm-petrel species show no moult415 breeding overlap while the Northern species do overlap both stages of the annual cycle. The 416 better relative energy availability of the Southern species during moult may be explained by the 417 fact that they change their feathers during the non-breeding period and can thus use all free 418 energy for feather synthesis. In contrast, the Northern species have to allocate their energy 419 between breeding and moulting. Our study shows how different moult-breeding strategies may 420 affect the relative energy availability or energy allocation during moult of migratory pelagic 421 seabirds. Additionally, we showed that at least a subset of the Procellariiformes likely forms two 422 growth bars per $24 \mathrm{~h}$ instead of one, probably associated with the diel migration of their main 423 prey species.

424

\section{$425 \quad$ Acknowledgements}

426 We would like to thank the Henryk Arctowski Polish Antarctic Station and the 427 Department of Antarctic Biology of the Polish Academy of Sciences for their hospitality and 428 logistic support during our stay on King George Island. We are indebted to Jens-Kjeld Jensen 429 and Marita Gulklett for their hospitality and help on the Faroe Islands. We are grateful also to the 430 three anonymous reviewers of our paper that helped us improve its quality. Lastly, we would like 431 to thank Rosanne Michielsen, Rachel Shepherd and Jessica Hey for their support in the field. 432

\section{$433 \quad$ References}

434 Ainley, D. G., Lewis, J. \& Morrell, S. (1976). Molt in Leach's and Ashy storm-petrels. The $435 \quad$ Wilson Bulletin, 88(1), 76-95.

436 Ainley, D. G., O'Connor, E. F. \& Boekelheide, R. J. (1984). The marine ecology of birds in the $437 \quad$ Ross Sea, Antarctica. Ornithological Monographs (Vol. 32).

$438 \quad$ https://doi.org/10.2307/40166773

439 Ainslie, J. A. \& Atkinson, R. (1936). On the breeding habits of Leach's fork-tailed petrel.

$440 \quad$ British Birds, 30, 234-249.

441 Alonso, H., Matias, R., Granadeiro, J. P. \& Catry, P. (2009). Moult strategies of Cory’s

442 shearwaters Calonectris diomedea borealis: The influence of colony location, sex and

$443 \quad$ individual breeding status. Journal of Ornithology, 150(2), 329-337.

$444 \quad$ https://doi.org/10.1007/s10336-008-0354-2

445 Amengual, J. F., Gargallo, G., Suárez, M., Bonnin, J., González, J. M., Rebassa, M. \& McMinn, 446 M. (1999). The Mediterranean storm petrel Hydrobates pelagicus melitensis at Cabrera 447 archipelago (Balearic Islands, Spain): Breeding moult, biometry and evaluation of the $448 \quad$ population size by mark and recapture techniques. Ringing and Migration, 19(3), 181449 190. https://doi.org/10.1080/03078698.1999.9674180 
450 Arrigo, K. R., van Dijken, G. L. \& Bushinsky, S. (2008). Primary production in the Southern

451

452
$454 \quad$ flight feathers of European storm-petrel Hydrobates pelagicus in Atlantic and

$455 \quad$ Mediterranean breeding areas. Ardeola, 51(2), 365-373.

456 Barbraud, C. \& Chastel, O. (1998). Southern fulmars molt their primary feathers while

457 incubating. The Condor, 100(3), 563-566.

458 Barlow, K. E., Boyd, I. L., Croxall, J. P., Reid, K., Staniland, I. J. \& Brierley, A. S. (2002). Are 459 penguins and seals in competition for Antarctic krill at South Georgia? Marine Biology, $460 \quad 140$ (2), 205-213. https://doi.org/10.1007/s00227-001-0691-7

461 Beck, J. R. \& Brown, D. W. (1971). Breeding biology of the black-bellied storm-petrel. Ibis, $462 \quad 113,73-90$.

463 Beck, J. R. \& Brown, D. W. (1972). The biology of Wilson's storm petrel, Oceanites oceanicus 464 465 (Kuhl), at Signy Island, South Orkney Islands. British Antarctic Survey Scientific Reports, 69, 1-54.

466 Bolton, M. \& Thomas, R. (2001). Moult and ageing of storm petrels Hydrobates pelagicus. $467 \quad$ Ringing and Migration, 20(3), 193-201.

$468 \quad$ https://doi.org/10.1080/03078698.2001.9674244

469 Bonitz, F. G. W., Andersson, C., Trofimova, T. \& Hátún, H. (2018). Links between

470 phytoplankton dynamics and shell growth of Arctica islandica on the Faroe Shelf. $471 \quad$ Journal of Marine Systems, 179, 72-87. https://doi.org/10.1016/j.jmarsys.2017.11.005

472 Bost, C. A., Cotté, C., Bailleul, F., Cherel, Y., Charrassin, J. B., Guinet, C., Ainley, D.G., 473 Weimerskirch, H. (2009). The importance of oceanographic fronts to marine birds and 474 mammals of the Southern oceans. Journal of Marine Systems, 78(3), 363-376.

$475 \quad$ https://doi.org/10.1016/j.jmarsys.2008.11.022

476 Bridge, E. S. (2006). Influences of morphology and behavior on wing-molt strategies in

477 seabirds. Marine Ornithology, 34(1), 7-19.

$478 \quad$ https://doi.org/10.1111/j.1472-4642.2007.0034.x

479 Büßer, C., Kahles, A. \& Quillfeldt, P. (2004). Breeding success and chick provisioning in

480 Wilson's storm-petrels Oceanites oceanicus over seven years: Frequent failures due to

481 food shortage and entombment. Polar Biology, 27(10), 613-622.

482 https://doi.org/10.1007/s00300-004-0627-z

483 Carbonell, R. \& Tellería, J. L. (1999). Feather traits and ptilochronology as indicators of stress 484 in Iberian blackcaps Sylvia atricapilla. Bird Study, 46(2), 243-248.

485 https://doi.org/10.1080/00063659909461136

486 Carboneras, C., Jutglar, F., Kirwan, G. M., Christie, D. A., Jutglar, F., Kirwan, G. M. \& Sharpe, 487 C. J. (2017). Order Procellariiformes. In J. del Hoyo, A. Elliot, J. Sargatal, D. A. Christie 488 \& E. de Juana (Eds.), Handbook of the Birds of the World Alive (pp. 197-278).

489 Barcelona: Lynx Edicions. Retrieved from http://www.hbw.com/node/52595 
490 Catry, P., Lemos, R. T., Brickle, P., Phillips, R. A., Matias, R. \& Granadeiro, J. P. (2013).

491

492

493

494

495

496

497

498

499

500 Predicting the distribution of a threatened albatross: The importance of competition, fisheries and annual variability. Progress in Oceanography, 110, 1-10. https://doi.org/10.1016/j.pocean.2013.01.005

Cimprich, D. A. \& Grubb, T. C. (1994). Consequences for Caroline chickadees of foraging with tufted titmice in winter. Ecology, 75(6), 1615-1625. https://doi.org/10.2307/1939622

Cramp, S., Simmons, K. E. L., Ferguson-Lees, I. J., Gillmor, R., Hollom, P. A. D., Hudson, R., Nicholson, E. M., Ogilvie, M.A., Olney, P.J.S., Voous, K. H. \& Wattel, J. (1977). Family Hydrobatidae storm-petrels. In Handbook of the Birds of Europe and the Middle East and North Africa The Birds of the Western Palearctic Volume I (pp. 155-178).

501 Crossin, G. T., Phillips, R. A., Lattin, C. R., Romero, L. M. \& Williams, T. D. (2013). 502 Corticosterone mediated costs of reproduction link current to future breeding. General 503 and Comparative Endocrinology, 193, 112-120.

$504 \quad$ https://doi.org/10.1016/j.ygcen.2013.07.011

505 Croxall, J. P. \& North, A. W. (1988). Fish prey of Wilson's storm petrel Oceanites oceanicus at $506 \quad$ South Georgia. British Antarctic Survey Bulletin, 78, 37-42.

507 Croxall, J. P. \& Prince, P. A. (1980). Food, feeding ecology and segregation of seabirds at South $508 \quad$ Georgia. Biological Journal of the Linnean Society, 14, 103-131.

509 Davis, P. (1957). The breeding of the storm-petrel. British Birds 50, 85-101, 371-387.

510 D’Elbée, J. \& Hémery, G. (1998). Diet and foraging behaviour of the British storm petrel $511 \quad H y d r o b a t e s$ pelagicus in the Bay of Biscay during summer. Ardea 86, 1-10.

512 de la Hera, I., DeSante, D. F. \& Milá, B. (2012). Feather growth rate and mass in Nearctic 513 passerines with variable migratory behavior and molt pattern. The Auk, 129(2), 222-230. $514 \quad$ https://doi.org/10.1525/auk.2012.11212

515 de la Hera, I., Pérez-Tris, J. \& Tellería, J. L. (2009). Repeatable length and mass but not growth 516 rate of individual feathers between moults in a passerine bird. Acta Ornithologica, 44(1), 517 95-99. https://doi.org/10.3161/000164509X464939

518 de la Hera, I., Pérez-Tris, J. \& Tellería, J. L. (2009). Migratory behaviour affects the trade-off 519 between feather growth rate and feather quality in a passerine bird. Biological Journal of 520 the Linnean Society, 97(1), 98-105. https://doi.org/10.1111/j.1095-8312.2008.01189.x 521 de la Hera, I., Pérez-Tris, J. \& Tellería, J. L. (2010). Relationships among timing of moult, 522 moult duration and feather mass in long-distance migratory passerines. Journal of Avian 523 Biology, 41(6), 609-614. https://doi.org/10.1111/j.1600-048X.2010.05075.x

524 de la Hera, I., Schaper, S. V, Díaz, J. A., Pérez-Tris, J., Bensch, S. \& Tellería, J. L. (2011). How 525 much variation in the molt duration of passerines can be explained by the growth rate of 526 tail feathers? The Auk, 128(2), 321-329. https://doi.org/10.1525/auk.2011.10181 527 Descamps, S., Tarroux, A., Cherel, Y., Delord, K., Godø, O. R., Kato, A., Krafft, B. A., 528 Lorentsen, S.H., Ropert-Coudert, Y., Skaret, G. \& Varpe, Ø. (2016). At-sea distribution 
529

530

531

532

533

and prey selection of Antarctic petrels and commercial krill fisheries. PLoS ONE, 11(8), 1-18. https://doi.org/10.1371/journal.pone.0156968

Dolby, A. S. \& Grubb, T. C. (1998). Benefits to satellite members in mixed-species foraging groups: An experimental analysis. Animal Behaviour, 56(2), 501-509.

534 Eliasen, S. K. (2017). Primary production on the Faroe shelf - Spatial and temporal variations $535 \quad$ with links to hydrography, PhD Thesis, Faculty of Science and Technology University of 536 the Faroe Islands, http://www.hav.fo/PDF/Ritgerdir/SolvaPhD.pdf

537 Ericson, P. G., Anderson, C. L., Britton, T., Elzanowski, A., Johansson, U. S., Källersjö, M., 538 Ohlson, J. I., Parsons, T. J., Zuccon, D. \& Mayr, G. (2006). Diversification of Neoaves: 539 integration of molecular sequence data and fossils. Biology Letters, 2, 543-547

540 Food and Agriculture Organization of the United Nations (2019). Species fact sheets Euphausia $541 \quad$ superba. http://www.fao.org/fishery/species/3393/en Accessed on 11.12.2018.

542 Flood, R. L. \& Thomas, B. (2007). Identification of "black-and-white" storm-petrels of the $543 \quad$ North Atlantic. British Birds, 100, 407-442.

544 Furness, R. W., \& Baillie, S. R. (1981). Factors affecting capture rate and biometrics of storm $545 \quad$ petrels on St Kilda. Ringing \& Migration, 3(3), 137-148.

$546 \quad$ https://doi.org/10.1080/03078698.1981.9673772

547 Green, J. A., Aitken-Simpson, E. J., White, C. R., Bunce, A., Butler, P. J. \& Frappell, P. B.

548 (2013). An increase in minimum metabolic rate and not activity explains field metabolic

549 rate changes in a breeding seabird. Journal of Experimental Biology, 216(9), 1726-1735. 550 https://doi.org/10.1242/jeb.085092

551 Grubb, T. C. (1989). Ptilochronology - feather growth bars as indicators of nutritional-status.

$552 \quad$ AUK, 106(2), 314-320.

553 Grubb, T. C. (2006). Ptilochronology. Oxford: Oxford University Press.

554 Grubb, T. C. \& Cimprich, D. A. (1990). Supplementary food improves the nutritional condition 555 of wintering woodland birds: evidence from ptilochronology. Ornis Scandinavica, 21(4), 556 277-281.

557 Grubb, T. C., Waite, J. T. A. \& Wiseman, A. J. (1991). Ptilochronology: induced feather growth 558 in Northern cardinals varies with age, sex, ambient temperature, and day length. The $559 \quad$ Wilson Bulletin, 103(3), 435-445.

560 Grubb, T. C. \& Yosef, R. (1994). Habitat-specific nutritional condition in loggerhead shrikes 561 (Lanius ludovicianus): Evidence from ptilochronology. The Auk, 111(3), 756-759.

562 Jetz W., Thomas, G. H., Joy, J. B., Hartmann, K., \& Mooers, A. O. (2012) The global diversity $563 \quad$ of birds in space and time. Nature, 491, 444-448

564 Hargitai, R., Hegyi, G., Herényi, M., Laczi, M., Nagy, G., Rosivall, B., Szöllösi, E. \& Török, J. 565 (2014). Winter body condition in the Collared Flycatcher: Determinants and carryover 566 effects on future breeding parameters. The Auk 131, 257-264. 
567 Hahn, S., Peter, H., Quillfeldt, P. \& Reinhardt, K. (1998). The birds of the Potter Peninsula, 568 King George Island, South Shetland Islands, Antarctica, 1965-1998. Marine $569 \quad$ Ornithology, 26(1995), 1-6.

570 Hedd, A. \& Montevecchi, W. A. (2006). Diet and trophic position of Leach's storm-petrel

571 Oceanodroma leucorhoa during breeding and moult, inferred from stable isotope

572 analysis of feathers. Marine Ecology Progress Series, 322, 291-301.

$573 \quad$ https://doi.org/10.3354/meps322291

574 Hedenström, A. \& Sunada, S. (1999). On the aerodynamics of moult gaps in birds. Journal of 575 Experimental Biology, 202, 67-76.

576 Hemborg, C., Sanz, J. \& Lundberg, A. (2001). Effects of latitude on the trade-off between 577 reproduction and moult: A long-term study with pied flycatcher. Oecologia, 129(2), 578 206-212. https://doi.org/10.1007/s004420100710

579 Hill, G. E. \& Montgomerie, R. (1994). Plumage colour signals nutritional condition in the house $580 \quad$ finch. Proceedings: Biological Sciences, 258(1351), 47-52.

581 ICES. (2005). Report of the ICES Advisory Council of the Sea 2005. Faroe Plateau Ecosystem. $582 \quad$ (Vol. 4).

583 ICES. (2008). Report of the ICES Advisory Committee 2008. Book 4.

584 Jovani, R., Blas, J., Navarro, C. \& Mougeot, F. (2011). Feather growth bands and photoperiod.

$585 \quad J o u r n a l$ of Avian Biology, 42(1), 1-4. https://doi.org/10.1111/j.1600-048X.2010.05175.X

586 Lago, P., Austad, M., \& Metzger, B. J. (2019). Partial migration in the Mediterranean Storm

587 Petrel (Hydrobates pelagicus melitensis). Marine Ornithology, 47, 105-113.

588 Langston, N. E. \& Rohwer, S. (1996). Molt-breeding tradeoffs in albatrosses: life history

589 implications for big birds. Oikos, 76(3), 498-510.

590 le Tortorec, E., Helle, S., Suorsa, P., Sirkiä, P., Huhta, E., Nivala, V. \& Hakkarainen, H. (2012).

$591 \quad$ Feather growth bars as a biomarker of habitat fragmentation in the Eurasian treecreeper.

$592 \quad$ Ecological Indicators, 15(1), 72-75. https://doi.org/10.1016/j.ecolind.2011.09.013

593 Lindström, Å., Visser, G. H. \& Daan, S. (1993). The energetic cost of feather synthesis to basal

594 metabolic rate is proportional. Physiological Zoology, 66(4), 490-510.

$595 \quad$ https://doi.org/10.2307/30163805

596 Maciorowski, G., Yosef, R., Väli, Ü., \& Tryjanowski, P. (2018). Nutritional Condition of

$597 \quad$ Hybrid Nestlings Is Similar To That of Pure-Species Offspring of Spotted Eagles

598 (Clanga clanga $\times$ C. pomarina). Journal of Raptor Research, 52(4), 484-491.

599 Marzal, A., Asghar, M., Rodríguez, L., Reviriego, M., Hermosell, I. G., Balbontín, J., Garcia-

600 Longoria, L., de Lope, F. \& Bensch, S. (2013). Co-infections by malaria parasites

601 decrease feather growth but not feather quality in house martin. Journal of Avian

602 Biology, 44(5), 437-444. https://doi.org/10.1111/j.1600-048X.2013.00178.x

603 Matysioková, B. \& Remeš, V. (2010). Assessing the usefulness of ptilochronology in the study 604 of melanin- and carotenoid-based ornaments in the great tit Parus major. Ibis, 152(2),

605 397-401. https://doi.org/10.1111/j.1474-919X.2009.01002.x 
606 Mauck, R. A. \& Grubb, T. C. (1995). Petrel parents shunt all experimentally increased

607 reproductive costs to their offspring. Animal Behaviour, 49(4), 999-1008.

608 https://doi.org/10.1006/anbe.1995.0129

609 Minguez, E. (1998). The Costs of Incubation in the British Storm-Petrel : An Experimental 610 Study in a Single- Egg Layer. Journal of Avian Biology, 29(2), 183-189.

611 Mumme, R. L. (2018). The trade-off between molt and parental care in hooded warblers: 612 Simultaneous rectrix molt and uniparental desertion of late-season young. The Auk, 613 135(3), 427-438. https://doi.org/10.1642/AUK-17-240.1

614 Murphy, E. J., Cavanagh, R. D., Drinkwater, K. F., Grant, S. M., Heymans, J. J., Hofmann, Hunt 615 Jr, G. L. \& Johnston, N. M. (2016). Understanding the structure and functioning of polar 616 pelagic ecosystems to predict the impacts of change. Proceedings of the Royal Society B: 617 Biological Sciences, 283, 20161646. https://doi.org/10.1098/rspb.2016.1646 618 Murphy, M. E. \& King, J. R. (1991). Ptilochronology : A Critical Evaluation of Assumptions 619 and Utilities. The Auk,108, 695-704.

620 Navarro, J. \& González-Solís, J. (2007). Experimental increase of flying costs in a pelagic 621 seabird: Effects on foraging strategies, nutritional state and chick condition. Oecologia, 622 151(1), 150-160. https://doi.org/10.1007/s00442-006-0559-0

623 Penhallurick, J. \& Wink, M. (2004). Analysis of the taxonomy and nomenclature of the 624 Procellariiformes based on complete nucleotide sequences of the mitochondrial 625 cytochrome b gene. Еmu, 72(2), 249-266.

626 Pérez-Tris, J., Carbonell, R. \& Tellería, J. L. (2002). Parasites and the blackcap's tail: 627 Implications for the evolution of feather ornaments. Biological Journal of the Linnean 628 Society, 76(4), 481-492. https://doi.org/10.1046/j.1095-8312.2002.00083.x

629 Pratte, I., Boadway, K. A., Diamond, A. W. \& Mallory, M. L. (2018). Changes in isotopic 630 niches across stages of the annual cycle in the Arctic tern (Sterna paradisaea). Arctic, $63171(3), 259-268$.

632 Quillfeldt, P. (2002). Seasonal and annual variation in the diet of breeding and non-breeding 633 Wilson's storm-petrels on King George Island, South Shetland Islands. Polar Biology, 634 25, 216-221. https://doi.org/10.1007/s00300-001-0332-0

635 R Core Team. (2018). R: A language and environment for statistical computing. Vienna, 636 Austria: R Foundation for Statistical Computing. Retrieved from https://www.r$637 \quad$ project.org

638 Ramos, R., Llabrés, V., Monclús, L., López-Béjar, M. \& González-Solís, J. (2018). Costs of 639 breeding are rapidly buffered and do not affect migratory behavior in a long-lived bird $640 \quad$ species. Ecology, 99(9), 2010-2024. https://doi.org/10.1002/ecy.2435

641 Ramos, R., Militão, T., González-Solís, J. \& Ruiz, X. (2009). Moulting strategies of a long642 distance migratory seabird, the Mediterranean Cory's shearwater Calonectris diomedea 643 diomedea. Ibis, 151(1), 151-159. https://doi.org/10.1111/j.1474-919X.2008.00877.x 644 Ratcliffe, N., Hill, S. L., Staniland, I. J., Brown, R., Adlard, S., Horswill, C. \& Trathan, P. N. 645 (2015). Do krill fisheries compete with macaroni penguins? Spatial overlap in prey 
646

647

648 Rheindt, F. E. \& Austin, J. J. (2005). Major analytical and conceptual shortcomings in a recent 649 taxonomic revision of the Procellariiformes - A reply to Penhallurick and Wink (2004). $650 \quad$ Emu, 105(2), 181-186. https://doi.org/10.1071/MU04039

651 Ridoux, V. (1994). The diets and dietary segregation of seabirds at the subantarctic Crozet 652 Islands. Marine Ornithology, 22(1), 1-192.

653 Robertson, B. C., Stephenson, B. M., Ronconi, R. A., Goldstien, S. J., Shepherd, L., Tennyson, 654 A., Carlile, N. \& Ryan, P. G. (2016). Phylogenetic affinities of the Fregetta storm655 petrels are not black and white. Molecular Phylogenetics and Evolution, 97, 170-176. $656 \quad$ https://doi.org/10.1016/j.ympev.2016.01.004

657 Rohwer, S., Ricklefs, R. E., Rohwer, V. G. \& Copple, M. M. (2009). Allometry of the duration 658 of flight feather molt in birds. PLoS Biology, 7(6), 1-9.

659 https://doi.org/10.1371/journal.pbio.1000132

660 Rohwer, V. G. \& Rohwer, S. (2013). How do birds adjust the time required to replace their 661 flight feathers? The Auk, 130(4), 699-707. https://doi.org/10.1525/auk.2013.13042 662 Ross, R. M. \& Quetin, L. B. (2014). How productive are Antarctic krill? Recent research is 663 challenging some long-held assumptions about the fecundity and development of $664 \quad$ Euphausia superba. BioScience, 36(4), 264-269.

665 Saino, N., Romano, M., Caprioli, M., Ambrosini, R., Rubolini, D., Scandolara, C. \& Romano, 666 A. (2012). A ptilochronological study of carry-over effects of conditions during 667 wintering on breeding performance in the barn swallow Hirundo rustica. Journal of $668 \quad$ Avian Biology 43, 513-524.

669 Sanz-Aguilar, A., Tavecchia, G., Minguez, E., Massa, B., Lo Valvo, F., Ballesteros, G. A., 670 Barberá, G.G., Amengual, J. F., Rodríguez, A., McMinn, M. \& Oro, D. (2010).

671 Recapture processes and biological inference in monitoring burrow-nesting seabirds.

$672 \quad J o u r n a l$ of Ornithology, 151(1), 133-146. https://doi.org/10.1007/s10336-009-0435-X

673 Siegel, V. (2012). Krill stocks in high latitudes of the Antarctic Lazarev sea: Seasonal and 674 interannual variation in distribution, abundance and demography. Polar Biology, 35(8),

675 1151-1177. https://doi.org/10.1007/s00300-012-1162-y

676 Slagsvold, T. \& Dale, S. (1996). Disappearance of female pied flycatchers in relation to

677 breeding stage and experimentally induced molt. Ecology, 77(2), 461-471.

678 Stutchbury, B. J. M., Gow, E. A, Done, T., MacPherson, M., Fox, J. W. \& Afanasyev, V. 679 (2011). Effects of post-breeding moult and energetic condition on timing of songbird 680 migration into the tropics. Proceedings of the Royal Society B: Biological Sciences, $681278(1702), 131-137$. https://doi.org/10.1098/rspb.2010.1220

682 Terrill, R. S. (2018). Feather growth rate increases with latitude in four species of widespread 683 resident Neotropical birds. The Auk, 135(4), 1055-1063. https://doi.org/10.1642/AUK$684 \quad 17-176.1$ 
685 Waite, T. A. (1990). Effects of caching supplemental food on induced feather regeneration in

686 wintering gray jays Perisoreus canadensis: a ptilochronology study. Ornis Scandinavica, 687 21(2), 122-128. https://doi.org/10.2307/3676807

688 Wasilewski, A. (1986). Ecological aspects of the breeding cycle in the Wilson's storm petrel, 689 Oceanites oceanicus (Kuhl), at King George Island (South Shetland Islands, Antarctica). $690 \quad$ Polish Polar Research, 7(3), 173-216.

691 Watanuki, Y. \& Thiebot, J. B. (2018). Factors affecting the importance of myctophids in the diet 692 of the world's seabirds. Marine Biology, 165, 1-14

693 White, D. W. \& Kennedy, E. D. (1992). Growth of induced feathers in photostimulated

694 American tree sparrows. The Condor, 94(2), 543-545. https://doi.org/10.2307/1369230

695 White, D. W., Kennedy, E. D. \& Stouffer, P. C. (1991). Feather regrowth in female European

696 starlings rearing broods of different sizes. The Auk, 108(4), 889-895.

697 https://doi.org/10.1016/j.ress.2016.07.018

698 Yosef, R. (1997). On habitat-specific nutritional condition in graceful warblers Prinia gracilis:

699 Evidence from ptilochronology. Journal für Ornithologie, 138(3), 309-313.

$700 \quad$ https://doi.org/10.1007/BF01651556

701 Yosef, R., Kubicka, A. M., Brandsma, M., \& Tryjanowski, P. (2018). A tale of two tails:

702 asymmetry in Great Grey Shrike (Lanius excubitor). Avian Research, 9 (1), 1. 


\section{Table 1 (on next page)}

Results of the post-hoc Dunn test for inter-specific differences in feather length (FL) and feather growth rate (FGR) for each studied species.

Var $=$ variable, $p$-values $\leq \alpha / 2(\alpha=0.05)$ are bolded 


\begin{tabular}{|c|c|c|c|c|c|c|c|}
\hline \multirow{3}{*}{$\begin{array}{l}\text { Species } \\
\text { European storm-petrel }\end{array}$} & \multirow{2}{*}{$\begin{array}{l}\text { Var } \\
\text { FL }\end{array}$} & \multicolumn{2}{|c|}{$\begin{array}{l}\text { black-bellied storm-petrel } \\
(\mathrm{Z}, \mathrm{p})\end{array}$} & \multicolumn{2}{|c|}{$\begin{array}{l}\text { European storm-petrel } \\
(\mathrm{Z}, \mathrm{p})\end{array}$} & \multicolumn{2}{|c|}{$\begin{array}{l}\text { Leach’s storm-petrel } \\
(\mathrm{Z}, \mathrm{p})\end{array}$} \\
\hline & & 12.177, & $<0.001$ & & & & \\
\hline & FGR & 10.363, & $<0.001$ & & & & \\
\hline \multirow[t]{2}{*}{ Leach’s storm-petrel } & FL & 0.698 , & 0.243 & -13.763 & $<0.001$ & & \\
\hline & FGR & 9.438, & $<0.001$ & -1.218 & 0.111 & & \\
\hline \multirow[t]{2}{*}{ Wilson's storm-petrel } & FL & 7.587 & $<0.001$ & -8.446 & $<0.001$ & 8.850 & $<0.001$ \\
\hline & FGR & 3.602 , & $<0.001$ & -10.831 & $<0.001$ & -9.528, & $<0.001$ \\
\hline
\end{tabular}




\section{Table 2 (on next page)}

Spearman's Rank Correlation output for correlations between feather growth rate (FGR) and feather length (FL) for each studied species.

$\mathrm{S}=$ sum of squared rank differences; rho $=$ Spearman's rank correlation rho. P-values $\leq 0.05$ are bolded. 
Species

rho

European storm-petrel

Leach's storm-petrel

Wilson's storm-petrel

black-bellied storm-petrel

27756
rho

1046299

1977.7

0.993

0.002

0.513

0.004 


\section{Table 3 (on next page)}

Phylogenetic generalized least squares (PGLS) models for feather growth rate (FGR) based on feather length (FL).

PGLS models, with Pagel's $\lambda$ based on the phylogenetic tree, were fitted to log 10 FGR as response variable and $\log 10 \mathrm{FL}$ as predictor, for data found in literature ( $\mathrm{n}=164$ species) and this study ( $n=4$ species). To determine whether the Procellariiform species considered ( $n=6$ species) differed in number of growth bars (GB) formed per $24 h$, we added a group term (group $1=$ non-Procellariiformes, group $2=$ Procellariiformes) and its interaction to the full PGLS model (no. 1). Terms were dropped based on significance and improvement of AIC (no. 2 \& 3). To test whether Langston and Rohwer's (1996) suggestion that Procellariiformes might form two GBs per $24 \mathrm{~h}$ was true, Procellariiformes FGR was doubled (PGLSadj model) and an analogous set of models were tried. Pagel's $\lambda$ is the phylogenetic signal, with values between 0 and 1 . All p-values $\leq 0.05$ are bolded. 


\begin{tabular}{|c|c|c|c|c|c|c|c|c|}
\hline Model & No. & Predictor & AIC & Pagel's $\lambda$ & Estimate & SE & t-value & $\operatorname{Pr}(>|t|)$ \\
\hline \multirow{9}{*}{ PGLS } & \multirow{4}{*}{1} & Intercept & \multirow[t]{4}{*}{-497.59} & \multirow[t]{4}{*}{0.935} & -0.500 & 0.107 & -4.669 & $<0.001$ \\
\hline & & $\log 10(\mathrm{FL})$ & & & 0.531 & 0.043 & 12.320 & $<0.001$ \\
\hline & & Group & & & -0.156 & 0.402 & -0.388 & 0.699 \\
\hline & & Log10(FL):Group & & & -0.067 & 0.194 & -0.347 & 0.729 \\
\hline & \multirow{3}{*}{2} & Intercept & \multirow[t]{3}{*}{-499.47} & \multirow[t]{3}{*}{0.935} & -0.493 & 0.105 & -4.708 & $<0.001$ \\
\hline & & $\log 10(\mathrm{FL})$ & & & 0.527 & 0.042 & 12.588 & $<0.001$ \\
\hline & & Group & & & -0.294 & 0.068 & -4.309 & $<0.001$ \\
\hline & \multirow{2}{*}{3} & Intercept & \multirow[t]{2}{*}{-484.99} & \multirow[t]{2}{*}{0.962} & -0.590 & 0.112 & -5.288 & $<0.001$ \\
\hline & & $\log 10(\mathrm{FL})$ & & & 0.554 & 0.045 & 12.374 & $<0.001$ \\
\hline \multirow{9}{*}{ PGLSadj } & \multirow{4}{*}{1} & Intercept & \multirow[t]{4}{*}{-497.59} & \multirow[t]{4}{*}{0.935} & -0.500 & 0.107 & -4.669 & $<0.001$ \\
\hline & & $\log 10(\mathrm{FL})$ & & & 0.531 & 0.043 & 12.320 & $<0.001$ \\
\hline & & Group & & & 0.145 & 0.402 & 0.361 & 0.719 \\
\hline & & Log10(FL):Group & & & -0.067 & 0.194 & 0.347 & 0.729 \\
\hline & \multirow{3}{*}{2} & Intercept & \multirow[t]{3}{*}{-499.47} & \multirow[t]{3}{*}{0.935} & -0.493 & 0.105 & -4.708 & $<0.001$ \\
\hline & & Log10(FL) & & & 0.527 & 0.042 & 12.588 & $<0.001$ \\
\hline & & Group & & & 0.008 & 0.068 & 0.110 & 0.912 \\
\hline & \multirow{2}{*}{3} & Intercept & \multirow[t]{2}{*}{-501.46} & \multirow[t]{2}{*}{0.935} & -0.490 & 0.102 & -4.814 & $<0.001$ \\
\hline & & Log10(FL) & & & 0.527 & 0.041 & 12.760 & $<0.001$ \\
\hline
\end{tabular}




\section{Table 4 (on next page)}

AIC and $\triangle \mathrm{AIC}$ values of phylogenetic generalized least squares (PGLS) models.

A PGLS model with Pagel's $\lambda$ was fitted to log10 feather growth rate (FGR) with feather length (FL) and Group (non-Procellariiformes vs Procellariiformes). No 1 is the full model, $2 \& 3$ with the interaction, and the interaction and group dropped respectively. Models were fitted to raw data (PGLS model) and data with Procellariiformes feather growth rate doubled (PGLSadj). Model selection was based on AIC and $\triangle \mathrm{AIC}$ values. 
Manuscript to be reviewed

\begin{tabular}{|c|c|c|c|c|}
\hline Model & No. & $\mathrm{df}$ & AIC & $\Delta \mathrm{AIC}$ \\
\hline \multirow{3}{*}{ PGLS } & 1 & 6 & -497.59 & 1.88 \\
\hline & 2 & 5 & -499.47 & 0.00 \\
\hline & 3 & 4 & -484.99 & 14.48 \\
\hline \multirow{3}{*}{ PGLSadj } & 1 & 6 & -497.59 & 1.88 \\
\hline & 2 & 5 & -499.47 & 1.99 \\
\hline & 3 & 4 & -501.46 & 0.00 \\
\hline
\end{tabular}




\section{Table 5 (on next page)}

Results of non-parametric post-hoc Dunn test for the residuals of the storm-petrel species from the optimized pylogenetic generalized least squares (PGLS) model.

For the multi-species model, PGLS models were fitted to $\log 10$ feather growth rate (FGR) found in literature as response variable with $\log 10$ feather length (FL) as predictor. To test wether the Procellariiformes behaved differently from rother species, a group variable was added with group 1 being all non-Procellariiformes and group 2 being the Procellariiformes. The residuals of the predicted log10 FGR of the individuals per storm-petrel species were obtained by inserting individual FL into the model with group set to Procellariiformes, and comparing the predicted $\log 10$ FGR with $\log 10$ observed FGR. P-values $\leq \alpha / 2(\alpha=0.05)$ are bolded. For plots see Fig. 3. 
Dunn's multiple comparisons test

\begin{tabular}{|c|c|c|c|c|c|c|}
\hline Species & $\begin{array}{l}\text { black-bellied s } \\
(\mathrm{Z}, \mathrm{p})\end{array}$ & petrel & $\begin{array}{l}\text { European stc } \\
(\mathrm{Z}, \mathrm{p})\end{array}$ & petrel & $\begin{array}{l}\text { Leach's sto } \\
(\mathrm{Z}, \mathrm{p})\end{array}$ & petrel \\
\hline European storm-petrel & 8.389, & $<0.001$ & & & & \\
\hline Leach’s storm-petrel & 9.075, & $<0.001$ & 0.715, & 0.237 & & \\
\hline Wilson's storm-petrel & 2.228 & 0.013 & -9.646 , & $<0.001$ & -10.770 & $<0.001$ \\
\hline
\end{tabular}




\section{Table 6(on next page)}

One-sample Student's t-test output of the residuals of feather growth rate (FGR) of each studied species predicted by the optimized phylogenetic generalized least squares (PGLS) model.

For the multi-species model, PGLS models were fitted to $\log 10$ feather growth rate (FGR) found in literature as response variable with log10 feather length (FL) as predictor. To test wether the Procellariiformes behaved differently from results reported for other species, a group variable was added with group 1 being all non-Procellariiformes and group 2 being the Procellariiformes. The residuals of the predicted $\log 10$ FGR of the individuals per storm-petrel species were obtained by inserting individual $\mathrm{FL}$ into the model with group set to Procellariiformes, and comparing the predicted $\log 10$ FGR with $\log 10$ observed FGR. P-values $\leq \alpha / 2(\alpha=0.05)$ are bolded. For plots see Fig. 3 . 
Manuscript to be reviewed

\begin{tabular}{|l|r|r|r|r|r|r|}
\hline & \multicolumn{4}{|l|}{ Residuals } & \multicolumn{3}{l|}{ Residuals difference } \\
\cline { 2 - 8 } Species & $\begin{array}{l}\text { Mean } \\
\text { residuals }\end{array}$ & $\begin{array}{l}\text { 95\% CI } \\
\text { lower }\end{array}$ & \multicolumn{1}{l|}{$\begin{array}{l}\text { l5\% CI } \\
\text { upper }\end{array}$} & \multicolumn{1}{l|}{ t } & \multicolumn{1}{l|}{ df } & \multicolumn{1}{l|}{ p } \\
\hline European storm-petrel & -0.076 & -0.102 & -0.050 & -5.847 & 51 & $<\mathbf{0 . 0 0 1}$ \\
\hline Leach's storm-petrel & -0.106 & -0.132 & -0.081 & -8.367 & 54 & $<\mathbf{0 . 0 0 1}$ \\
\hline Wilson's storm-petrel & 0.122 & 0.113 & 0.132 & 25.310 & 199 & $<\mathbf{0 . 0 0 1}$ \\
\hline black-bellied storm-petrel & 0.154 & 0.132 & 0.176 & 14.460 & 28 & $<\mathbf{0 . 0 0 1}$ \\
\hline
\end{tabular}


Figure 1

Correlation between feather growth rate (FGR) and feather length (FL) for all four studied storm-petrel species.

European storm-petrels (ESP) are shown in purple; Leach's storm-petrels (LSP) in blue; Wilson's storm-petrels (WSP) in green; black-bellied storm-petrels (BBSP) in yellow. Species from the Northern Hemisphere are shown with dots, species from the Southern Hemisphere with triangles. See Table $1 \& 2$ for statistical analyses.

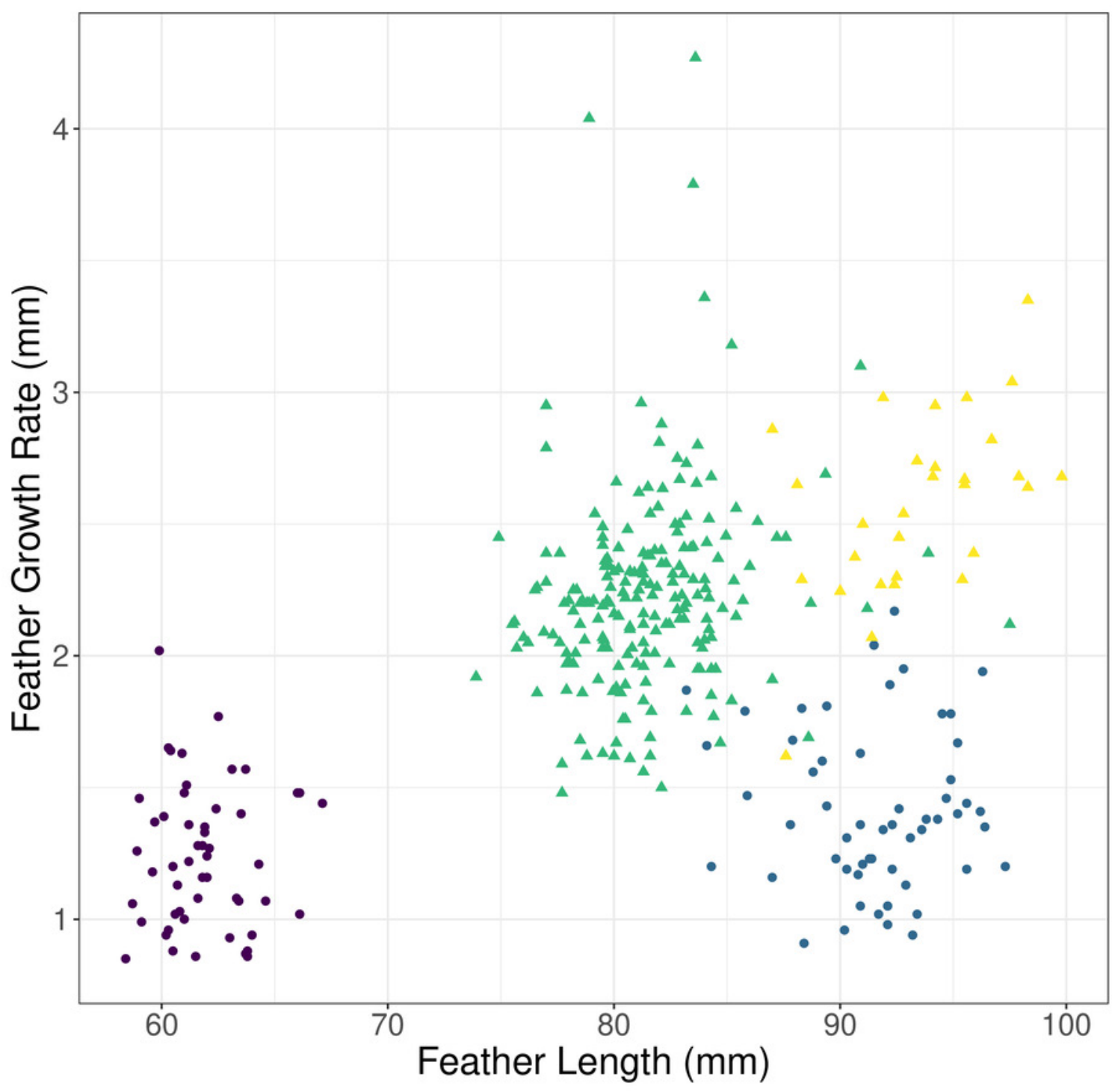

Hemisphere

- Northern

- Southern

Species

- ESP

- LSP

- WSP

BBSP 


\section{Figure 2}

Phylogenetic generalized least squares (PGLS) models for feather growth rate (FGR) based on feather length (FL).

(A) The optimized PGLS model, with Pagel's $\lambda$, based on the phylogenetic tree, was fitted to $\log 10 \mathrm{FGR}$ as response variable, and $\log 10 \mathrm{FL}$ and group as predictors, for data found in literature ( $n=164$ species) and this study ( $n=4$ species). The groups were defined as nonProcellariiformes and Procellariiformes, to determine whether the Procellariiformes behaved differently from the other reported species. The data used for this model were not adjusted. (B) The PGLS model with group as predictor and with Procellariiformes FGR doubled (PGLSadj model), following Langston and Rohwer's (1996) suggestion that Procellariiformes might form two GBs per $24 \mathrm{~h}$. The group term was not significant in this model, indicating that the aforementioned suggestion was likely correct. Procellariiformes are shown in yellow, nonProcellariiformes in purple. The studied species are circled in black (ESP = European stormpetrel, LSP $=$ Leach's storm-petrel, WSP $=$ Wilson's storm-petrel, BBSP = black-bellied stormpetrel). See also Table 3 for model description and Table 4 for model comparison. 


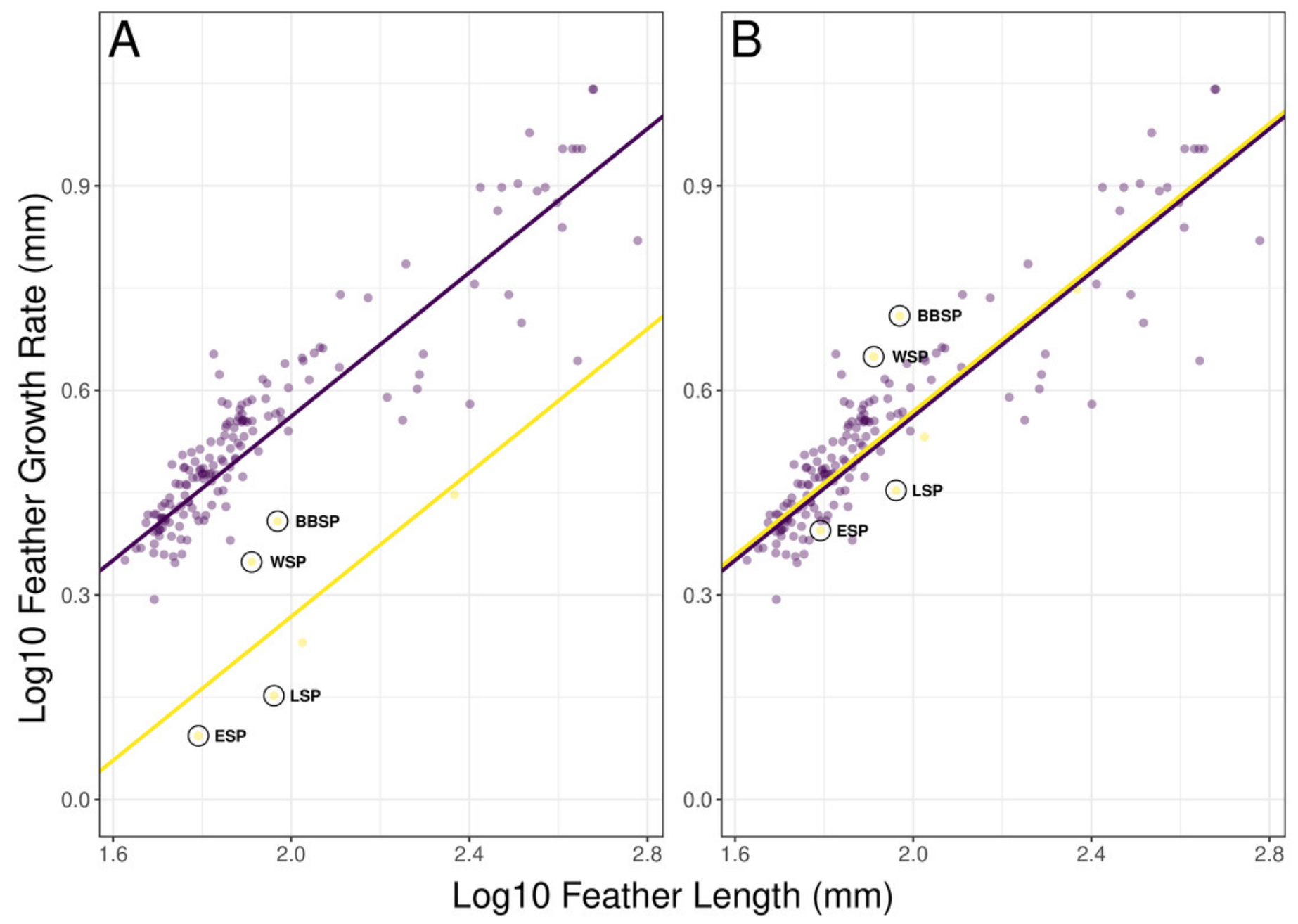

Order Non-Procellariiformes Procellariiformes 


\section{Figure 3}

Predicted feather growth rates (FGR) and their residuals based on the optimized phylogenetic generalized least squares (PGLS) model for individual storm-petrels.

(A) Individual FGR was predicted (open points) using the optimized PGLS model (i.e. log10 FGR log10 FL + group, where FL is feather length and groups were specified as nonProcellariiformes vs Procellariiformes), and residuals were calculated based on the distance to the observed values (closed points). Individual FL was used for model prediction and group was set to Procellariiformes. The Northern species are represented by dots, the Southern by triangles. European storm-petrels (ESP) are shown in purple; Leach's storm-petrels (LSP) in blue; Wilson's storm-petrels (WSP) in green; black-bellied storm-petrels (BBSP) in yellow. (B) The density plot shows residual distribution from the optimized PGLS model. The dotted line shows a residual length of 0.0 . The Northern species are represented by solid lines, the Southern species by dashed lines. The colour codes are the same as in panel A. For statistical comparisons between the species and hemispheres see Table $5 \&$ main text, and for species mean deviation from zero see Table 6 . 

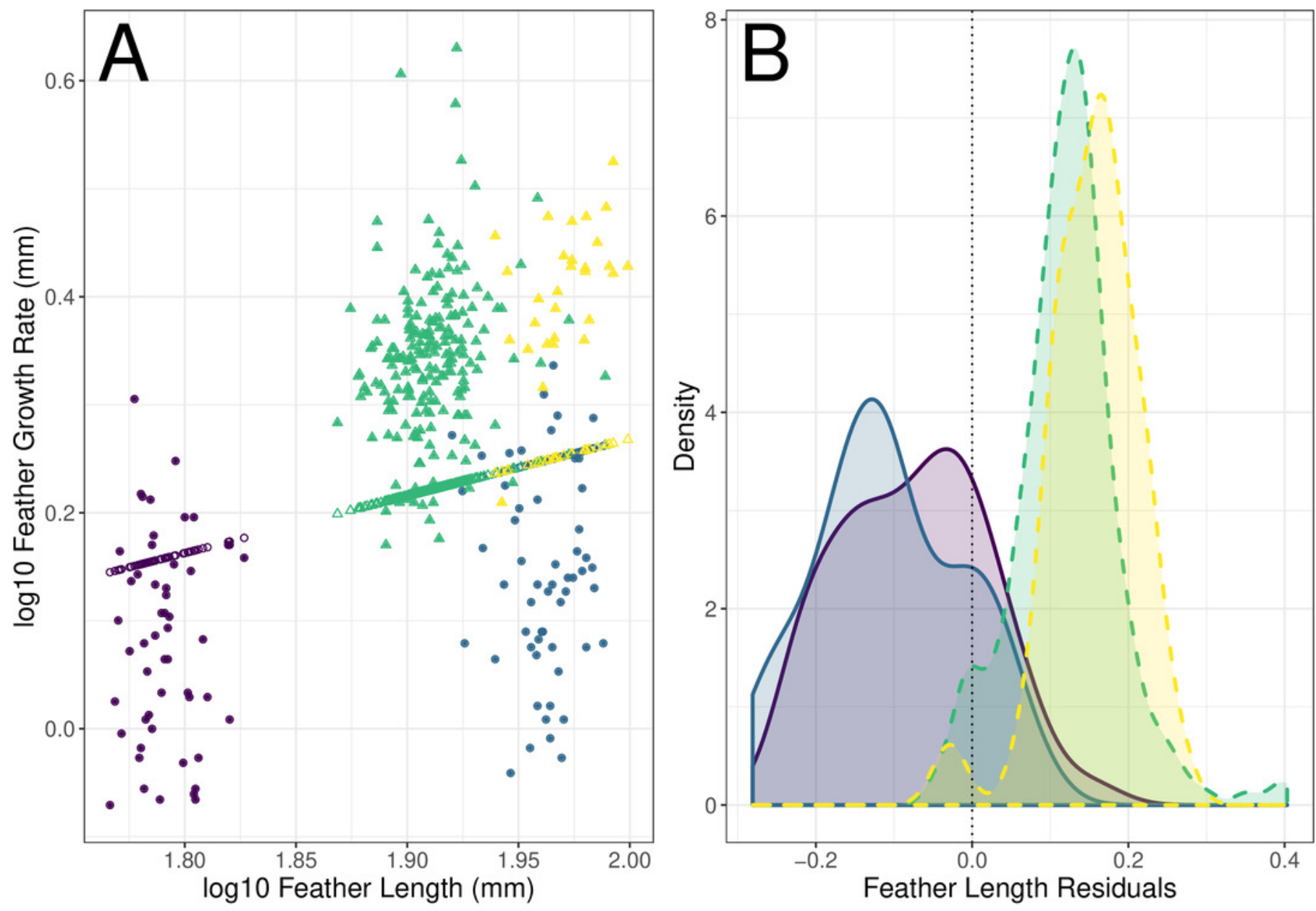

Species Hemisphere

Species

Hemisphere

- ESP $\triangle$ WSP $\circ$ Northern

\begin{tabular}{lll}
$\square$ ESP ㄴ. WSP \\
\hline LSP & BBSP
\end{tabular}

$\square$ Northern

- LSP $\triangle$ BBSP $\triangle$ Southern 